\title{
DETERMINATION OF ANTIMICROBIAL ACTIVITIES OF CRUDE ALKALOID EXTRACTED FROM THE STEMS OF Tinospora cordifolia Miers.
}

\author{
Dr Tu Tu Wai ${ }^{1}$, Dr Than Than Cho ${ }^{2}$, Dr San San Wai ${ }^{3,}$ Dr Yin Yin Myat ${ }^{4}$ and Dr San Yu Khaing ${ }^{5}$ \\ ${ }^{1}$ Lecturer in Chemistry Department Mandalay University, \\ Myanmar, tutuwaichemistry2260@gmail.com \\ 2,4,5 - Lecturer in Chemistry Department, Yadanabon University \\ 3 - Lecturer in Chemistry Department, Myingyan Degree College \\ DOI: $10.31364 / S C I R J / v 7 . i 8.2019 . P 0819690$ \\ http://dx.doi.org/10.31364/SCIRJ/v7.i8.2019.P0819690
}

\begin{abstract}
Tinospora cordifolia Miers. is a large, glabrous, deciduous climbing shrub belonging to the family Menispermaceae. The qualitative phytochemical screening of the stems of Tinospora cordifolia Miers. was determined by using standard methods. The stems of Tinospora cordifolia Miers. revealed the presence of alkaloids, flavonoids, terpenoids, phenolic compounds, saponins, tannins, glycosides and carbohydrates, and showed the absence of steroids and reducing sugars. The quantitative crude alkaloid was extracted from the stems of Tinospora cordifolia Miers. by using Harbone J.B. Method. The percentage yield of the crude alkaloid was found to be $2.008 \%$. And the antimicrobial activities of crude alkaloid extracts in various solvent systems were tested by using agar well diffusion method on six selected organisms, such as Bacillus subtilis, Staphylococcus aureus, Pseudomonas aeruginosa, Bacillus pumilus, Candida albicans and Escherichia coli.
\end{abstract}

Keywords: Tinospora cordifolia Miers., stems, crude alkaloid, Harbone J.B. method and antimicrobial activities

\section{INTRODUCTION}

Mankind has used many plants for medicinal purposes for thousands of years. Natural products have been traditionally accepted as remedies for many diseases. The beneficial medicinal effects of plant products typically result from the combinations of secondary metabolites present. Plant extracts have been known since antiquity to possess notable biological activities, including antibacterial, antioxidant, and anticancer properties (Tilburt JC, Kaptchuk TJ.,2008).

An alkaloid is a naturally occurring nitrogen-containing compound, which shows a basic. It is assumed that alkaloids are produced by the plant as a type of defense against insects and herbivores. They are usually bitter tasting, and often have psychoactive properties. About $80 \%$ of plant alkaloids possess anti-inflammatory properties but isoquinoline (berbamine, berberine, cepharanthine and tetrandine) is the most active (Yang L, Stöckigt J.,2010).

Among the medicinal plants, Tinospora cordifolia Miers. belongs to the family Menispermaceae which consists of about 70 genera and 450 species that are found in tropical lowland regions. This family is a rich source of alkaloid and terpenes. Myanmar and India are its native countries. It is widely available for sale in local markets, herbal stores etc. Flowers and fruits grow during summer and during winter. The leaves afford a good fodder for cattle. Tinospora cordifolia Miers., has showed no side effect and toxicity. It is reported to possess antispasmodic, anti-inflammatory and antiallergic properties (Bhalerao et al., 2016).

Aim

The main aim of this research is to determine the antimicrobial activities of crude alkaloid extracted from the stems of Tinospora cordifolia Miers.

\subsection{Botanical Description of Tinospora cordifolia Miers}

$\begin{array}{llc}\text { Scientific name } & : & \text { Tinospora cordifolia Miers } \\ \text { Family } & : & \text { Menispermaceae } \\ \text { English name } & : & \text { Heart-leaved Moon seed } \\ \text { Myanmar name } & : & \text { Sindone-ma-nwe }\end{array}$

$\begin{array}{lll}\text { Locality } & : & \text { Tropical regions of Myanmar } \\ \text { Habi } & : & \text { Climber } \\ \text { Parts used } & : & \text { Stems }\end{array}$




\section{MATERIALS AND METHODS}

\subsection{Sample Collection and Preparation}

The stems of Tinospora cordifolia Miers. were collected from Myitkyina University campus, Kachin state in August 2018. The stems of this selected medicinal plant were thoroughly washed with tap water, cut into small pieces and air dried for one month, and then stored in airtight glass bottles.
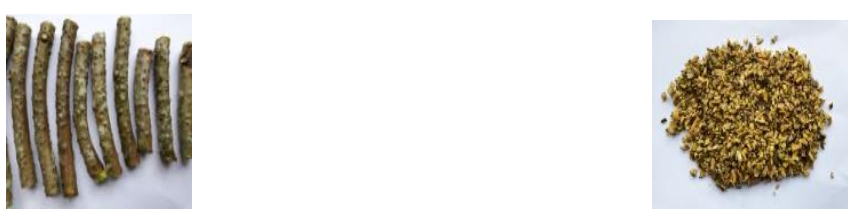

\subsection{Preliminary Phytochemical Analysis of the stems of Tinospora cordifolia Miers.}

Phytochemical screening of the stem of Tinospora cordifolia Miers. was performed for the qualitative detection of alkaloids, flavonoids, terpenoids, phenolic compounds, steroids, saponins, tannins, glycosides, carbohydrates and reducing sugar by using standard procedures.

\subsection{Extraction of Alkaloids from the stems of Tinospora cordifolia Miers.}

A $5 \mathrm{~g}$ of the ground stems of Tinospora cordifolia Miers. was added to a $250 \mathrm{ml}$ beaker and $200 \mathrm{ml}$ of $10 \%$ acetic acid in ethanol was added and covered and allowed to stand for $4 \mathrm{hr}$. it was filtered and this extract was concentrated on a water bath to one-quarter of the original volume. Concentrated ammonium hydroxide was added drop wise to the extract until the precipitation was complete. The whole solution was allowed to settle and the precipitate was collected and washed with $1 \%$ ammonium hydroxide solution and then filtered. The residue is the alkaloid, which was dried and weighed. As stated above, this extraction procedure was carried out for three times using (5) g of dried sample per extraction. About $0.04 \mathrm{~g}$ of the dried residue was dissolved in $3 \mathrm{~mL}$ distilled water. Dragendroff's reagent was added to it. The crude alkaloid was confirmed by performing which shows the appearance of orange colored precipitate using Dragendroff's reagent (Harborne, J.B.,1973). The percentage yield of crude alkaloid was calculated using the following formula:

$$
\% \text { yield }=\frac{\text { weight of the alkaloid residue } x 100}{\text { weight of ground stems of Tinospora cordifolia Miers. }}
$$

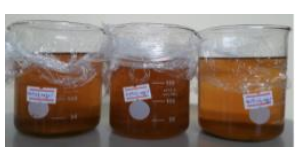

Figure 1. $5 \mathrm{~g}$ of the sample in $200 \mathrm{~mL}$ of $10 \%$ acetic acid in ethanol for $4 \mathrm{hr}$

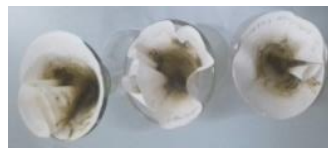

Figure 2. Crude alkaloid residue on the filter paper

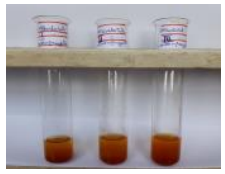

Figure 3. Crude Alkaloid test with Dragendroff's reagent

\subsection{Determination of Antimicrobial Activities of Crude Alkaloid}

The antimicrobial activities of the stems of Tinospora cordifolia Miers. were evaluated at Pharmaceutical Research Department,Yangon by using agar well diffusion method on six selected organisms that include three gram positive bacteria, Bacillus subtilis, Bacillus pumilus and Staphylococcus aureus, two gram negative bacteria, Pseudomonas aeruginosa and Escherichia coli, and fungi, Candida albicans.

\section{RESULTS AND DISCUSSION}

In this research work, phytochemical screening and crude alkaloid extraction of the stems of Tinospora cordifolia Miers. were carried out. And the antimicrobial activities of crude alkaloid were also determined.

\subsection{Phytochemical Screening of the Stems of Tinospora cordifolia Miers.}

The results of the preliminary screening of the stems of Tinospora cordifolia Miers. are shown in Figure 4. and Table 1. 


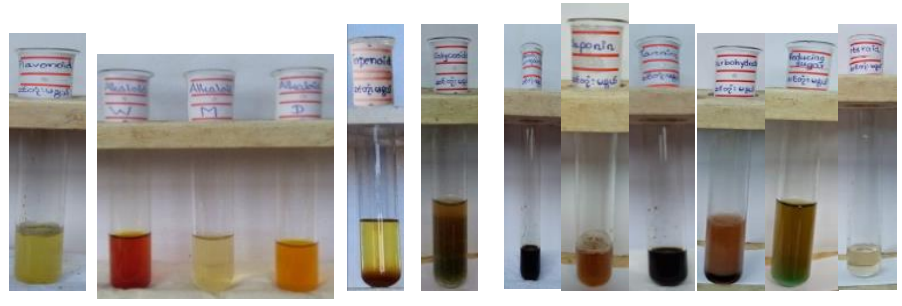

Figure 4. Phytochemical Analysis of the Stems of Tinospora cordifolia Miers.

Table1. Phytochemical Screening of the Stems of Tinospora cordifolia Miers.

\begin{tabular}{|c|c|c|c|c|}
\hline No. & Tests & Extracts & Test reagents & Observation \\
\hline 1 . & Alkaloids & $1 \% \mathrm{HCl}$ & $\begin{array}{l}\text { Dragendroff's reagent } \\
\text { Wagner's reagent }\end{array}$ & $\begin{array}{l}\text { Orange colored ppt } \\
\text { reddish brown colored } \\
\text { ppt }\end{array}$ \\
\hline & & & Mayer's reagent & cream colored ppt \\
\hline 2. & Flavonoids & EtOH & Mg turning, conc: $\mathrm{HCl}$ & $\begin{array}{l}\text { Greenish yellow color } \\
\text { solution }\end{array}$ \\
\hline 3. & Terpenoids & $\mathrm{EtOH}$ & $\begin{array}{l}\mathrm{CHCl}_{3}, \\
\text { conc: } \mathrm{H}_{2} \mathrm{SO}_{4}\end{array}$ & Reddish brown colored ppt \\
\hline 4. & $\begin{array}{l}\text { Phenolic } \\
\text { compounds }\end{array}$ & EtOH & $10 \% \mathrm{FeCl}_{3}$ & Black color solution \\
\hline 5. & Steroids & $\mathrm{CHCl}_{3}$ & $\begin{array}{l}\text { Acetic anhydride, } \\
\text { conc: } \mathrm{H}_{2} \mathrm{SO}_{4}\end{array}$ & No Green color solution \\
\hline 6. & Saponins & $\mathrm{H}_{2} \mathrm{O}$ & Distilled water & Frothing \\
\hline \multirow[t]{2}{*}{7.} & Tannins & & $10 \% \mathrm{FeCl}_{3}$ & Dark brown color solution \\
\hline & & $\mathrm{H}_{2} \mathrm{O}$ & & \\
\hline 8. & Glycosides & $\mathrm{H}_{2} \mathrm{O}$ & $10 \%$ lead acetate & White ppt \\
\hline 9. & Carbohydrates & $\mathrm{H}_{2} \mathrm{O}$ & $\begin{array}{l}10 \% \propto \text {-naphthol, } \\
\text { conc: } \mathrm{H}_{2} \mathrm{SO}_{4}\end{array}$ & $\begin{array}{l}\text { Violet color ring of the } \\
\text { interface of the two layers }\end{array}$ \\
\hline 10. & Reducing sugar & $\mathrm{H}_{2} \mathrm{O}$ & Benedict's solution & brick-red colored ppt \\
\hline
\end{tabular}
$(+) \quad=$ Presence of constituents
$(-) \quad=$ Absence of constituents

According to these results, the stems of Tinospora cordifolia Miers. showed the presence of alkaloids, flavonoids, terpenoids, phenolic compounds, saponins, tannins, glycosides and carbohydrates and the absence of steroids and reducing sugars. These phytochemicals of the stems of Tinospora cordifolia Miers. are unique health compounds that are essential to human health.

\subsection{Determination of the Percentage Yield of Crude Alkaloid extracted from the Stems of Tinospora cordifolia Miers.}

The results of crude alkaloid of Tinospora cordifolia Miers. are shown in Table2.

Table 2. The Percentage Yield of Crude Alkaloid extracted from the stems of

\begin{tabular}{|c|c|c|c|}
\hline No & $\begin{array}{l}\begin{array}{l}\text { Weight of } \\
\text { Tinospora } \\
\text { Miers. stems } \\
\text { cordifolia }\end{array} \\
\text { (gram) }\end{array}$ & $\begin{array}{l}\text { Weight of the alkaloid } \\
\text { residue } \\
\text { (gram) }\end{array}$ & $\%$ yield \\
\hline 1 & 5 & 0.1003 & 2.006 \\
\hline 2 & 5 & 0.1005 & 2.010 \\
\hline 3 & 5 & 0.1004 & 2.008 \\
\hline & 5 & 0.1004 & 008 \\
\hline
\end{tabular}

The average yield percent of the crude alkaloid content in the stems of Tinospora cordifolia Miers. was quantitatively found to be $2.008 \%$. This data signifies that the stems of Tinospora cordifolia Miers. in general has the highest percentage yield. The most popular reagent, Dragendorff's reagent reacts with tertiary and quaternary nitrogen atoms present in alkaloid molecules. Therefore, this crude alkaloid may contain berberine, colchicine, canadine, atropine, nicotine and tubocurarine, but may not 
involve alkaloids containing primary and secondary amino groups (norephedrine and ephedrine). According to the current results, the stems of Tinospora cordifolia Miers. hold an important bioactive compounds.

\subsection{Antimicrobial Activities of Crude Alkaloid}

The results of antimicrobial activities of crude alkaloid extracted from the stems of Tinospora cordifolia Miers. are shown in Figure 5 and Table 3.
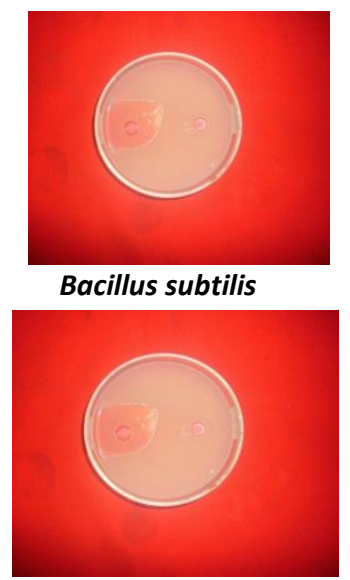

Bacillus pumilus
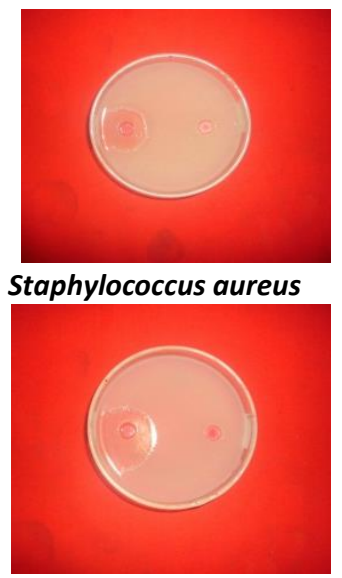

Candida albicans
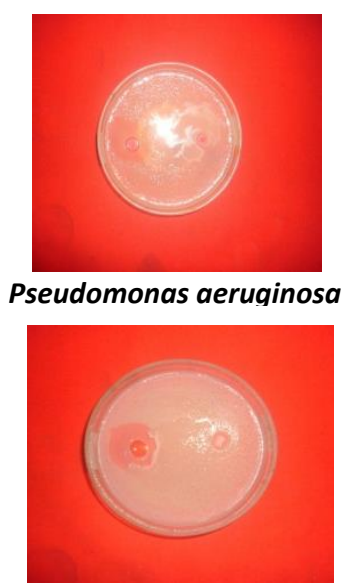

E. coli

Figure 5. Antimicrobial activities of crude alkaloid extracted from the stems of Tinospora cordifolia Miers.

Table 3. Results of Antimicrobial Activities of crude Alkaloid Extracted from the Stems of

Tinospora cordifolia Miers.

\begin{tabular}{|c|c|c|c|c|c|c|c|c|c|}
\hline \multirow{2}{*}{ Sample } & \multicolumn{9}{|c|}{ Inhibition zone diameters of crude alkaloids against six microorganisms (mm) } \\
\hline & I & & II & & III & & IV & $\mathrm{V}$ & VI \\
\hline $\begin{array}{l}\text { crude } \\
\text { alkaloid }\end{array}$ & $\begin{array}{l}30 \\
(+++)\end{array}$ & $\mathrm{mm}$ & $\begin{array}{l}25 \\
(+++)\end{array}$ & $\mathrm{mm}$ & $\begin{array}{l}30 \\
(+++)\end{array}$ & $\mathrm{mm}$ & $\begin{array}{l}30 \mathrm{~mm} \\
(+++)\end{array}$ & $\begin{array}{l}30 \mathrm{~mm} \\
(+++)\end{array}$ & $\begin{array}{l}25 \mathrm{~mm} \\
(+++)\end{array}$ \\
\hline
\end{tabular}

Agar well - $10 \mathrm{~mm}$

$10 \mathrm{~mm} \sim 14 \mathrm{~mm}(+)$

$15 \mathrm{~mm} \sim 19 \mathrm{~mm}(++)$

$20 \mathrm{~mm}$ above $(+++)$
Organisms

(I) Bacillus subtilis

(II) Staphylococcus aureus

(III) Pseudomonas aeruginosa

(IV) Bacillus pumilus

(V) Candida albicans

(VI) Escherichia coli

According to these results, the crude alkaloid extracted from the stems of Tinospora cordifolia Miers. showed high activities on all tested organisms. The antimicrobial activities of crude alkaloid demonstrate that folk medicine could be as effective as modern medicine to combat pathogenic microorganisms.

\section{CONCLUSION}

Phytochemical screening of the stems of Tinospora cordifolia Miers. contained alkaloids, flavonoids, terpenoids, phenolic compounds, saponins, tannins, glycosides and carbohydrates but showed the absence of steroids and reducing sugars. These qualitative phytochemicals of the stems of Tinospora cordifolia Miers. are responsible for showing considerable antimicrobial, antioxidant and anticancer activities. The significant amount of crude alkaloid was found to be $2.008 \%$. And the antimicrobial activities of crude alkaloid extracted from the stems of Tinospora cordifolia Miers. showed high activities on all tested organisms. The stems of Tinospora cordifolia Miers. could serve as a potential source of useful drugs. Further works are needed to isolate, characterize and elucidate the structures of the bioactive compounds in the stems of Tinospora cordifolia Miers. for pharmacological active constituents. 


\section{REFERENCES}

Bhalerao et al.( 2016). "Tinospora cordifolia (Thunb.) Miers (Guduchi) - An Overview" Vol.5, No.1, 001-012.

Harborne, J.B. (1973). "Phytochemical methods", Chapman and Hall Ltd., London. pp. 49-188.

Tilburt JC, Kaptchuk TJ. (2008). "Herbal medicine research and global health": an ethical analysis. Bull World Health Organ. 86(8):594-9.

Yang L, Stöckigt J.(2010). “Trends for diverse production strategies of plant medicinal alkaloids”. Nat Prod Rep.27:1469-79. 